\title{
Volatile Metabolomic Composition of Vitex Species: Chemodiversity Insights and Acaricidal Activity
}

José G. de Sena Filho', Ighor C. Barreto', Avaldo O. Soares Filho², Paulo C. L. Nogueira ${ }^{3}$, Adenir V. Teodoro ${ }^{1}$, Ana V. Cruz da Silva', Haroudo S. Xavier ${ }^{4}$, Allivia R. C. Rabbani ${ }^{5}$, Daniel J. Spakowicz ${ }^{6}$ and Jennifer M. Duringer ${ }^{7 *}$

\begin{abstract}
1 Empresa Brasileira de Pesquisa Agropecuária - EMBRAPA Tabuleiros Costeiros, Aracaju, Brazil, ${ }^{2}$ Herbário HUESBVC, Departamento de Ciências Naturais, Universidade Estadual do Sudoeste da Bahia, Conquista, Brazil, ${ }^{3}$ Laboratório de Pesquisa em Química Orgânica de Sergipe, Departamento de Química - CCET, Universidade Federal de Sergipe, São Cristóvão, Brazil, ${ }^{4}$ Departamento de Ciências Farmacêuticas, Universidade Federal de Pernambuco, Recife, Brazil, ${ }^{5}$ Bahia Federal Institute of Education, Science and Technology - IFBA, Porto Seguro, Brazil, ${ }^{6}$ Program in Comparative Biology and Bioinformatics, Yale University, New Haven, CT, United States, ${ }^{7}$ Department of Environmental and Molecular Toxicology, Oregon State University, Corvallis, OR, United States
\end{abstract}

OPEN ACCESS

Edited by:

Jens Rohloff,

Norwegian University of Science and Technology, Norway

Reviewed by: Ariaya Hymete Sahledingle, Addis Ababa University, Ethiopia Hartwig Schulz,

Julius Kühn-Institut, Germany

*Correspondence:

Jennifer M. Duringer Jennifer.Duringer@oregonstate.edu

Specialty section:

This article was submitted to Plant Metabolism and Chemodiversity, a section of the journal Frontiers in Plant Science

Received: 02 August 2017 Accepted: 25 October 2017 Published: 14 November 2017

Citation:

de Sena Filho JG, Barreto IC, Soares Filho AO, Nogueira PCL, Teodoro AV, Cruz da Silva AV, Xavier HS, Rabbani ARC,

Spakowicz DJ and Duringer JM (2017) Volatile Metabolomic Composition of Vitex Species: Chemodiversity Insights and Acaricidal Activity.

Front. Plant Sci. 8:1931. doi: 10.3389/fpls.2017.01931
The Vitex genus (Lamiaceae) produces a plethora of metabolites that include ecdysteroids and terpenoids, some of which have demonstrated insect repellent properties. The volatile composition of several members of this genus has not been chemically defined, as many taxa are endemic to remote ecosystems. In this study, leaves were collected from the northeast of Brazil from Vitex capitata, V. megapotamica, $V$. gardneriana, and $V$. rufescens plants and examined for their chemical profile via GC-MS/FID of essential oil extracts. The analyses showed a diversity of terpenoids. Of particular note were seven-member ring sesquiterpenes which were present in great abundance; a dendrogram showed clades separating by the production of bicyclogermacrene, aromadendrane and 5,10-cycloaromadendrane sesquiterpenoids for the four species. Comparison of volatile metabolite profiles to 13 other Vitex species showed strong similarities in the production of some monoterpenes, but varied by their production of larger terpenes, especially those with gem-dimethylcyclopropyl subunits on seven-member ring compounds. From this work, we suggest that the sesquiterpene skeleton with seven member rings is a good chemosystematic biomarker candidate for the Vitex genus. Separation using this biomarker was then validated using Inter-Simple Sequence Repeat profiling. Lastly, experiments examining the toxicity of these four oils against the coconut mite Aceria guerreronis showed that only the oil of $V$. gardneriana had strong acaricidal activity, with an $L C_{50}$ of $0.85 \mathrm{mg} / \mathrm{mL}$, thus demonstrating its potential for use as a natural pesticide.

Keywords: Vitex capitata, Vitex megapotamica, Vitex gardneriana, Vitex rufescens, chemodiversity

\section{INTRODUCTION}

Metabolomic profiles from organisms in the Plantae and other kingdoms have been used to distinguish samples from different species and ecotypes, as well as aid in their classification (Dettmer et al., 2007; Allwood et al., 2011; Aliferis et al., 2013; Jing et al., 2015). In the case of plants, much attention has been given to one of the largest group of metabolites they produce, 
the terpenoids. In a study similar to ours which explored the chemodiversity of Selaginella in the context of evolution, Weng and Noel (2013) suggest that monoterpene and sesquiterpene synthases are derived from conserved diterpene synthases, based off of phylogenetic analyses of plant terpene synthases done by Bohlmann et al. (1998). Thus, it appears that monoterpenes and sesquiterpenes are frequently used as chemical markers for distinguishing between genera. For example, in the Lantana (Verbenaceae) genus, $\beta$-caryophyllene was the major compound suggested as a chemical marker (Sena Filho et al., 2010), while in Citrus, both cyclic $(R-(+)$-limonene and $\alpha$-terpinene) and bicyclic monoterpenes ( $\alpha$-pinene and sabinene) were dominant in fruit essential oils and therefore proposed as markers for those species/varieties (Jing et al., 2015). Worldwide, the volatile metabolomics composition of Vitex species has been poorly investigated, likely due to their accessibility and phenotype, namely, their size and bad odor. From a total of 250 species, only about 35 are reported in the literature with in-depth chemical characterizations. Many of them are difficult to identify due to endemism, e.g., Vitex rufences A. Juss, Vitex capitata Vahl, Vitex gardneriana Schauer, which are found only in areas in the northeast of Brazil.

The main goal of this study was to develop a metabolomics approach for evaluating the volatile composition of Vitex species, using four species we collected (Vitex capitata Vahl, Vitex megapotamica (Spreng.) Moldenke, Vitex gardneriana Schauer and Vitex rufescens A. Juss) in addition to 13 Vitex species published in the literature. First, the chemical composition of the volatile fraction of essential oils from leaves of these species was characterized via GC-MS/FID. Subsequently, cluster analyses of the chemical composition of the 17 Vitex species were performed. Next, Inter-Simple Sequence Repeat (ISSR) was used to evaluate the genetic variation between our four Vitex species, followed by cluster analyses. Lastly, bioactivity of our four essential oil extracts was evaluated using toxicity assays against Aceria guerreronis Keifer (Acari: Eriophyidae), a major pest found in coconut plantations worldwide (Návia et al., 2013). From this study, we aimed to chemosystematically characterize the Vitex genus, in addition to expand our understanding of it in an evolutionary context.

\section{MATERIALS AND METHODS}

\section{Plant Material}

Leaves from V. capitata, V. megapotamica, V. gardneriana, and $V$. rufescens were collected in the northeast of Brazil during the rainy season in June of 2015. Determination of species was carried out by Prof. Dr. Avaldo de Oliveira Soares Filho, by comparison to exsiccates from the Universidade Estadual do Sudoeste da Bahia (HUESBVC) and specimens of virtual herbaria, in addition to use of technical bibliographies (Salimena-Pires and Giulietti, 1998; Barroso et al., 1999; Lima and Rança, 2009). Genus of taxonomic classification followed the Angiosperm Phylogenetic Group (APG III) guidelines. Vouchers of the specimens were deposited in the Herbarium of HUESVC in Vitoria da Conquista, Brazil, under the numbers 8194 (V. capitata), 8195
(V. megapotamica) and 8126 (V. gardneriana). V. rufescens was deposited under number 38352 in the Herbarium of the Universidade Federal de Sergipe (UFS) in Aracaju.

\section{Essential Oil Isolation Procedure}

Essential oils from fresh leaves (1 kg) were extracted via hydrodistillation for $4 \mathrm{~h}$ with a Clevenger-type apparatus (Sena Filho et al., 2010). The extracted oils were dried with powdered anhydrous sodium sulfate and kept at $4^{\circ} \mathrm{C}$ in a sealed amber bottle before analysis by GC-MS/FID.

\section{GC-MS/FID Analysis}

Essential oil characterization was performed using methods described previously (Bittrich et al., 2013; Ramos et al., 2013; Feitosa-Alcantara et al., 2017). Specifically, a GC-MS/FID (QP2010 Ultra, Shimadzu Corporation, Kyoto, Japan) equipped with an autosampler (AOC-20i, Shimadzu) was used to separate compounds with an $\mathrm{Rtx}^{\circledR}-5 \mathrm{MS}$ Restek fused silica capillary column (5\%-diphenyl-95\%-dimethyl polysiloxane) of $30 \mathrm{~m} \times 0.25 \mathrm{~mm}$ i.d., $0.25 \mu \mathrm{m}$ film thickness, at a constant helium (99.999\% purity) flow rate of $1.2 \mathrm{~mL} \cdot \mathrm{min}^{-1}$. An injection volume of $0.5 \mu \mathrm{L}$ was employed, with a split ratio of $1: 10$. The oven temperature program started at $60^{\circ} \mathrm{C}$, was held for $3 \mathrm{~min}$, then increased at a rate of $5^{\circ} \mathrm{C} / \mathrm{min}$ to $300^{\circ} \mathrm{C}$, and was finally held for 9 min. The MS and FID data were simultaneously acquired by employing a detector splitting system, with a split flow ratio of 5:1 (MS:FID). A $0.4 \mathrm{~m} \times 0.15 \mathrm{~mm}$ i.d. restrictor tube (capillary column) was used to connect the splitter to the MS detector, while a $0.6 \mathrm{~m} \times 0.22 \mathrm{~mm}$ i.d. restrictor tube was used to connect the splitter to the FID detector. The MS data were acquired in full scan mode $(m / z$ of $40-550)$ at a scan rate of $0.3 \mathrm{scan} / \mathrm{s}$ using an electron ionization potential of $70 \mathrm{eV}$. The injector temperature was set to $280^{\circ} \mathrm{C}$ and the ion source temperature to $200^{\circ} \mathrm{C}$. The FID temperature was $300^{\circ} \mathrm{C}$, and the gas supplies for the FID were hydrogen, air, and helium at flow rates of 30, 300, and $30 \mathrm{~mL} \cdot \mathrm{min}^{-1}$, respectively. Quantification of each constituent was estimated by FID peak-area normalization (\%). Compound concentrations were calculated from the GC peak areas relative to the total peak area of all peaks and were arranged in order of GC elution. The retention index was obtained by co-injecting the oil sample with a C7-C30 linear hydrocarbon mixture; identification was made based on comparison of retention indices and fragmentation patterns with published values (Linstrom and Mallard, 2005; Adams, 2007).

\section{Cluster Analyses of Essential Oil Volatile Metabolomic Composition}

Molecules comprising at least $2 \%$ of the total FID signal were summarized for the four Vitex species from this study as well as 13 species referenced in the literature (Supplementary Table S1). The cluster analysis was then carried out using the Euclidean Distance and the Unweighted Pair Group Method with Arithmetic Mean (UPGMA) cluster algorithm (Sokal and Michener, 1958). Statistical analysis was performed using the Paleontological Statistics Software Package for Education and Data Analysis (PAST) (Hammer et al., 2001). Dendrograms were 
then generated which assigned diversity of the 17 Vitex species based on their essential oil components.

\section{Genetic Analysis with ISSR Markers}

The four Vitex species we collected (Vitex capitata, V. megapotamica, V. gardneriana and $V$. rufescens) were analyzed by repeat sequence primers via Inter-Simple Sequence Repeat (ISSR). The DNA was extracted from young, fresh leaves as previously described (Doyle, 1991). Fourteen primers were used to screen for polymorphisms (Table 1). The PCR amplification parameters and ISSR method used followed that as described in Sena Filho et al. (2010).

\section{Cluster Analysis of Genetic Markers}

Based on the presence or absence of fragments, the polymorphic information content (PIC) (Ghislain et al., 1999), the marker index (MI) (Zhao et al., 2007), the similarity coefficient matrix (Jaccard, 1908), and the clustering of the matrix were calculated for each primer using the UPGMA cluster algorithm (Sokal and Michener, 1958). The bootstrap method was used with 100,000 replicates by employing FreeTree software (Pavlicek et al., 1999) to generate the dendrogram (Page, 1996).

\section{Toxicity to A. guerreronis}

Concentration-mortality bioassays (Silva et al., 2013) were conducted to estimate the lethal concentration (LC) of the essential oil extracted from four Vitex species ( $V$. capitata, $V$. megapotamica, $V$. gardneriana, and $V$. rufescens) to adult coconut mites (A. guerreronis). A preliminary bioassay was performed using a wide concentration range where the no observed adverse effect level (NOAEL) and the concentration able to kill $100 \%$ of A. guerreronis were determined. Afterward, four concentrations within this range were used to generate a concentration response curve as follows: oil was sprayed onto perianth disks ( $1 \mathrm{~cm}$ diameter) of young coconut fruits placed in Petri dishes containing agar at 5\%. Spraying of the oils was performed at a pressure of $34 \mathrm{kPa}(0.34$ bar) with a $9.3-\mathrm{ml}$ spray rate using a Potter Tower device (Burkard, Rickmansworth, United Kingdom) (Oliveira et al., 2017). Sprayed perianth disks were allowed to dry for $20 \mathrm{~min}$ before 20 adult $A$. guerreronis were placed onto each disk. Control disks were sprayed with acetone, which was also used to dissolve and dilute the oils for all concentrations. Petri dishes were individually maintained in an incubator at $26^{\circ} \mathrm{C}$ and $70 \%$ relative humidity for $24 \mathrm{~h}$. Eight replicates (wells) for each oil concentration were used. Harmfulness of the commercial acaricide abamectin (Vertimec $18 \mathrm{EC}^{\mathrm{TM}} ; 18 \mathrm{~g}$ a.i./L, at field dosage $75 \mathrm{~mL} / 100 \mathrm{~L}$ ) to A. guerreronis was evaluated as a way of toxicity comparison (20 replicates were performed and control disks were sprayed with distilled water). Mite mortality was assessed after $24 \mathrm{~h}$ of exposure and concentration-mortality curves were estimated by Probit analysis using the PROC PROBIT procedure in SAS (version 9.4, Cary, NC, United States). The likelihood ratio chi-square goodness-offit was applied to evaluate whether the data adequately conformed to the PROBIT model (Robertson et al., 2007).

\section{RESULTS}

GC-MS/FID analysis of essential oils collected from leaves of $V$. capitata, V. megapotamica, V. gardneriana and $V$. rufescens (yield of $0.13,0.18,0.33$, and $0.45 \%$, respectively) determined $46,45,41$, and 37 constituents to be present, respectively (Table 2). Grouping for the species by Euclidian distance based on seven-member ring sesquiterpenes showed clades separating by the production of bicyclogermacrene, aromadendrane and 5,1-cycloaromadendrane sesquiterpenoids, e.g., aromadendrene, viridiflorene, ledol, viridiflorol, allo-aromadendrene, bicyclogermacrene, globulol, 6,9-guaiadiene, spathulenol and palustrol (Figure 1). We then analyzed the volatile composition of the essential oils from 13 previously published Vitex species, as well as the four Vitex species studied here, three

TABLE 1 | Primer information for DNA markers used to screen for polymorphisms in four Vitex specimens gathered from northeastern Brazil.

\begin{tabular}{|c|c|c|c|c|c|}
\hline Code* & Forward primer $\left(5^{\prime}-3^{\prime}\right)$ & Annealing Temp $\left({ }^{\circ} \mathrm{C}\right)$ & NF & PIC & MI \\
\hline 809 & AGAGAGAAGAGAGA GG & $57.2^{\circ} \mathrm{C}$ & 5 & 0.34 & 1.70 \\
\hline 818 & CACACACACACACACAG & $57.2^{\circ} \mathrm{C}$ & 6 & 0.41 & 2.46 \\
\hline 823 & тСтСтСтСтСтСтСтСС & $57.2^{\circ} \mathrm{C}$ & 8 & 0.23 & 1.86 \\
\hline 826 & ACACACACACACACACC & $57.2^{\circ} \mathrm{C}$ & 9 & 0.34 & 3.09 \\
\hline 842 & GAGAGAGAGAGAGAGAYG & $58.8^{\circ} \mathrm{C}$ & 4 & 0.44 & 3.05 \\
\hline 843 & СТСТСТ СТСТСТСТСТRА & $56.5^{\circ} \mathrm{C}$ & 6 & 0.29 & 1.76 \\
\hline 845 & стстстстСTСTСTCTRG & $58.8^{\circ} \mathrm{C}$ & 2 & 0.23 & 0.46 \\
\hline 848 & CACACACACACACACCRG & $58.8^{\circ} \mathrm{C}$ & 6 & 0.35 & 2.11 \\
\hline 855 & ACACACACACACACACYT & $56.5^{\circ} \mathrm{C}$ & 7 & 0.28 & 1.99 \\
\hline 856 & ACACACACACACACACYA & $56.5^{\circ} \mathrm{C}$ & 9 & 0.35 & 3.17 \\
\hline 857 & ACACACACACACACYG & $58.8^{\circ} \mathrm{C}$ & 11 & 0.31 & 3.46 \\
\hline 858 & TGTGTGTGTGTGTGTGRT & $56.5^{\circ} \mathrm{C}$ & 7 & 0.30 & 2.07 \\
\hline 888 & BDBCACACACACACACA & $56.5^{\circ} \mathrm{C}$ & 2 & 0.32 & 0.65 \\
\hline 890 & VHVGTGTGTGTGTGTGT & $56.5^{\circ} \mathrm{C}$ & 8 & 0.18 & 1.43 \\
\hline
\end{tabular}

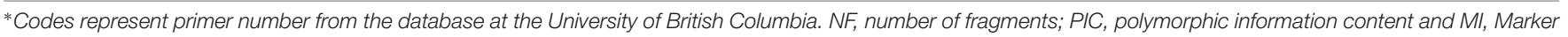
Index. 
TABLE 2 | Major components (\%) identified in the essential oil extracted from leaves of Vitex capitata, V. megapotamica, V. gardneriana and V. rufescens from northeastern Brazila ${ }^{2}$.

\begin{tabular}{|c|c|c|c|c|c|c|}
\hline RI lit. ${ }^{b}$ & RI exp. ${ }^{c}$ & Compounds & V. capitata & V. megapotamica & V. gardneriana & V. rufescens \\
\hline 846 & 865 & (2E)-Hexenal & - & - & - & $\operatorname{tr}^{d}$ \\
\hline 850 & 866 & (3Z)-Hexen-1-ol & - & - & - & 0.4 \\
\hline 863 & 876 & Hexan-1-ol & - & - & - & tr \\
\hline 932 & 934 & $\alpha$-Pinene & - & 0.3 & - & tr \\
\hline 974 & 965 & $\beta$-Pinene & - & 0.4 & - & - \\
\hline 974 & 981 & Oct-1-en-3-ol & - & - & - & tr \\
\hline 1024 & 1020 & Limonene & - & 0.1 & - & 0.1 \\
\hline 1067 & 1066 & cis-Linalool oxide (furanoid) & - & 0.1 & - & - \\
\hline 1084 & 1083 & trans-Linalool oxide (furanoid) & - & 0.1 & - & - \\
\hline 1095 & 1094 & Linalool & 0.2 & 1.1 & tr & $\operatorname{tr}$ \\
\hline 1122 & 1132 & $\alpha$-Campholenal & - & - & tr & - \\
\hline 1135 & 1146 & Nopinone & - & - & tr & - \\
\hline 1160 & 1171 & Pinocarvone & - & - & 0.1 & - \\
\hline 1174 & 1185 & Terpinen-4-ol & - & - & 0.2 & - \\
\hline 1184 & 1182 & Neoisomentol & $\operatorname{tr}$ & - & - & - \\
\hline 1186 & 1196 & $\alpha$-Terpineol & 0.1 & 0.2 & 0.1 & - \\
\hline 1195 & 1205 & Myrtenal & - & - & 0.2 & - \\
\hline 1284 & 1292 & Dihydroedulan IIA & - & - & - & tr \\
\hline 1292 & 1297 & Dihydroedulan IA & $\operatorname{tr}$ & - & - & tr \\
\hline 1298 & 1302 & Theaspirane & - & - & - & tr \\
\hline 1315 & 1319 & Theaspirane B & - & - & - & tr \\
\hline 1335 & 1341 & $\delta$-Elemene & 0.7 & 1.0 & 0.5 & 1.8 \\
\hline 1345 & 1353 & $\alpha$-Cubebene & 1.8 & 1.9 & 1.0 & $\operatorname{tr}$ \\
\hline 1369 & 1380 & Cyclosativene & tr & - & - & - \\
\hline 1373 & 1376 & $\alpha$-Ylangene & 0.1 & 0.1 & - & tr \\
\hline 1374 & 1380 & $\alpha$-Copaene & 11.7 & 10.8 & 3.2 & 0.3 \\
\hline 1379 & 1384 & $\beta$-Patchoulene & - & - & - & tr \\
\hline 1383 & 1393 & $(E)-\beta$-Damascenone & tr & 0.3 & 0.3 & - \\
\hline 1387 & 1389 & $\beta$-Bourbonene & tr & 1.3 & 0.6 & 0.6 \\
\hline 1389 & 1398 & $\beta$-Elemene & 2.2 & 2.7 & 1.9 & 5.8 \\
\hline 1409 & 1416 & $\alpha$-Gurjunene & 0.1 & 0.1 & - & 1.6 \\
\hline 1417 & 1430 & $(E)$-Caryophyllene & 19.7 & 16.2 & 2.7 & 21.0 \\
\hline 1430 & 1435 & $\beta$-Copaene & - & - & 0.5 & 0.8 \\
\hline 1434 & 1445 & $\gamma$-Elemene & 6.7 & 5.6 & - & - \\
\hline 1437 & 1451 & $\alpha$-Guaiene & 0.2 & 0.3 & 0.1 & - \\
\hline 1439 & 1456 & Aromadendrene & 0.3 & 0.2 & - & 0.3 \\
\hline 1442 & 1460 & (Z)- $\alpha$-farnesene & * & * & - & - \\
\hline 1442 & 1461 & 6,9-Guaiadiene & $0.3^{*}$ & $0.8^{*}$ & 19.3 & 0.3 \\
\hline 1451 & 1466 & trans-Muurola-3,5-diene & $\operatorname{tr}$ & 0.3 & 1.8 & - \\
\hline 1452 & 1473 & $\alpha$-Humulene & 15.7 & 8.5 & 0.9 & 7.3 \\
\hline 1458 & 1479 & allo-Aromadendrene & 1.9 & 2.3 & 0.5 & 6.9 \\
\hline 1465 & 1487 & cis-Muurola-4(14),5-diene & 0.1 & 0.2 & - & - \\
\hline 1475 & 1491 & trans-Cadina-1(6),4-diene & 1.3 & 2.1 & - & - \\
\hline 1464 & 1478 & 9-epi-(E)-Caryophyllene & - & - & - & 0.1 \\
\hline 1475 & 1481 & $\gamma$-Gurjunene & - & - & - & $0.6^{*}$ \\
\hline 1476 & 1481 & $\beta$-Chamigrene & - & - & - & * \\
\hline 1478 & 1491 & $\gamma$-Muurolene & 9.5 & 13.5 & 0.4 & 0.7 \\
\hline 1484 & 1499 & Germacrene D & - & - & 2.5 & 9.3 \\
\hline 1489 & 1504 & $\beta$-Selinene & 0.5 & 0.9 & 0.7 & 2.2 \\
\hline 1492 & 1496 & cis- $\beta$-Guaiene & - & - & - & tr \\
\hline 1493 & 1511 & trans-Muurola-4(14),5-diene & $\operatorname{tr}$ & $\operatorname{tr}$ & 1.0 & tr \\
\hline
\end{tabular}


TABLE 2 | Continued

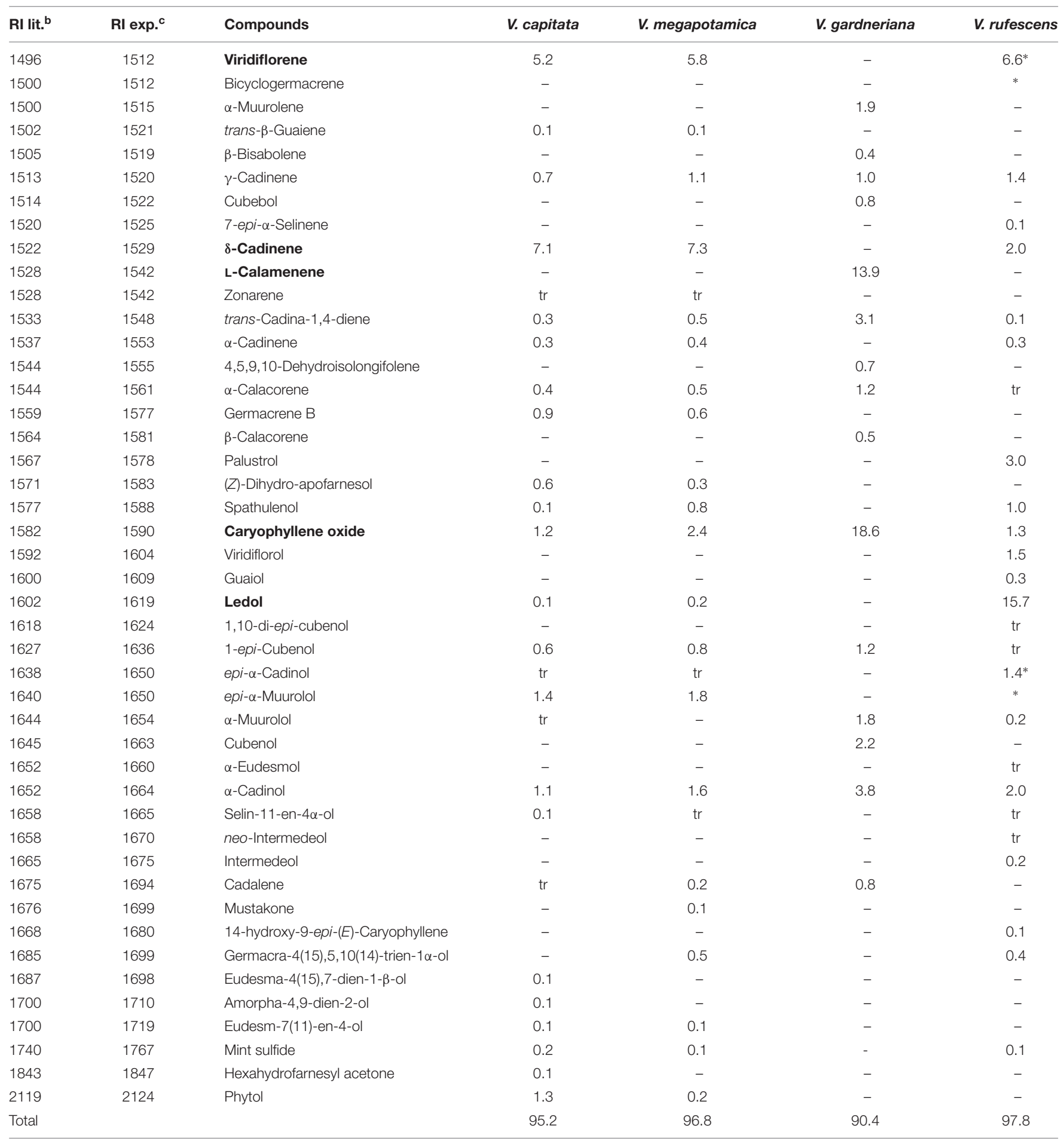

a Those compounds which are in bold represent the main compounds found. ${ }^{\mathrm{b}} \mathrm{Rl}$ lit., retention indices according to Adams (2007). ${ }^{\mathrm{c}} \mathrm{Rl}$ exp., retention indices on RTX-5MS column calculated according to van Den Dool and Kratz (1963). ${ }^{d}$ tr = trace amounts of compound were detected. ${ }^{*}$ co-eluting compounds.

of them endemic to Brazil (V. capitata, V. gardneriana and $V$. rufescens) via a clustering algorithm (Figure 2). The 17 species comparison showed strong similarities in the production of some monoterpenes, but varied by their production of larger terpenes, especially those with gem-dimethylcyclopropyl subunits on seven-member ring compounds.

The 14 ISSR primers generated a total of 90 fragments, $100 \%$ of which were polymorphic. The primer with the highest 


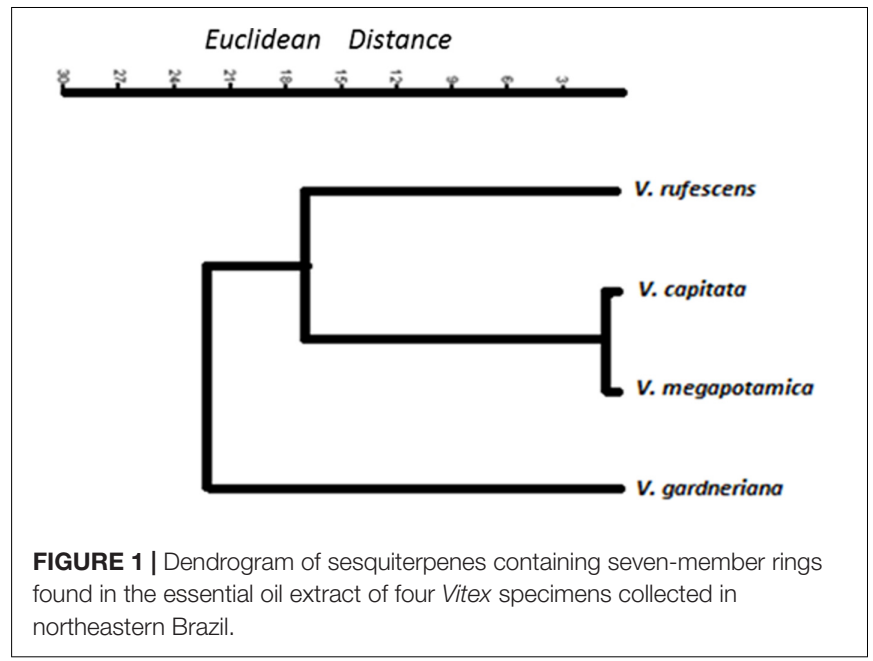

number of fragments was 857 (eleven), while the lowest were 845 and 888 (two). The values of PIC and MI are parameters that allow for estimation of the power of discrimination of the molecular marker by a primer; in our results, the primers 842 and 818 were the most informative (Table 1). We observed only fragments to $V$. capitata for primer 823. Genotypes were clustered by UPGMA using the Jaccard coefficient (JC), estimated from the binary data (Figure 3). The similarity mean was 0.21 JC $(0.08$ - 0.45 JC). We observed a clear separation of two groups, with $V$. gardneriana being the most isolated of the four species. In our study, ISSR fingerprints clearly distinguished all of the tested species, with cluster results similar to those performed for the chemical compounds (Figure 2).

In the biotoxicity assays, the essential oil extracted from $V$. gardneriana was highly toxic to A. guerreronis $\left(\mathrm{LC}_{50}\right.$ $0.8577 \mathrm{mg} / \mathrm{mL}$; CI $0.67-1.15 ; x^{2}=3.17$, df $=2, \mathrm{P}=0.20$ ). In contrast, it was not possible to estimate the $\mathrm{LC}_{50}$ from $V$. capitata, $V$. megapotamica and $V$. rufescens essential oils, as increasing concentrations $(0.1,0.5,1,1.5,1.8,2.0$, and $2.3 \mathrm{mg} / \mathrm{mL}$ ) of these oils did not kill adults of A. guerreronis over a period of $24 \mathrm{~h}$. As a way of toxicity comparison, the acaricide abamectin, sprayed at its label rate, inflicted $100 \%$ mortality to A. guerreronis.

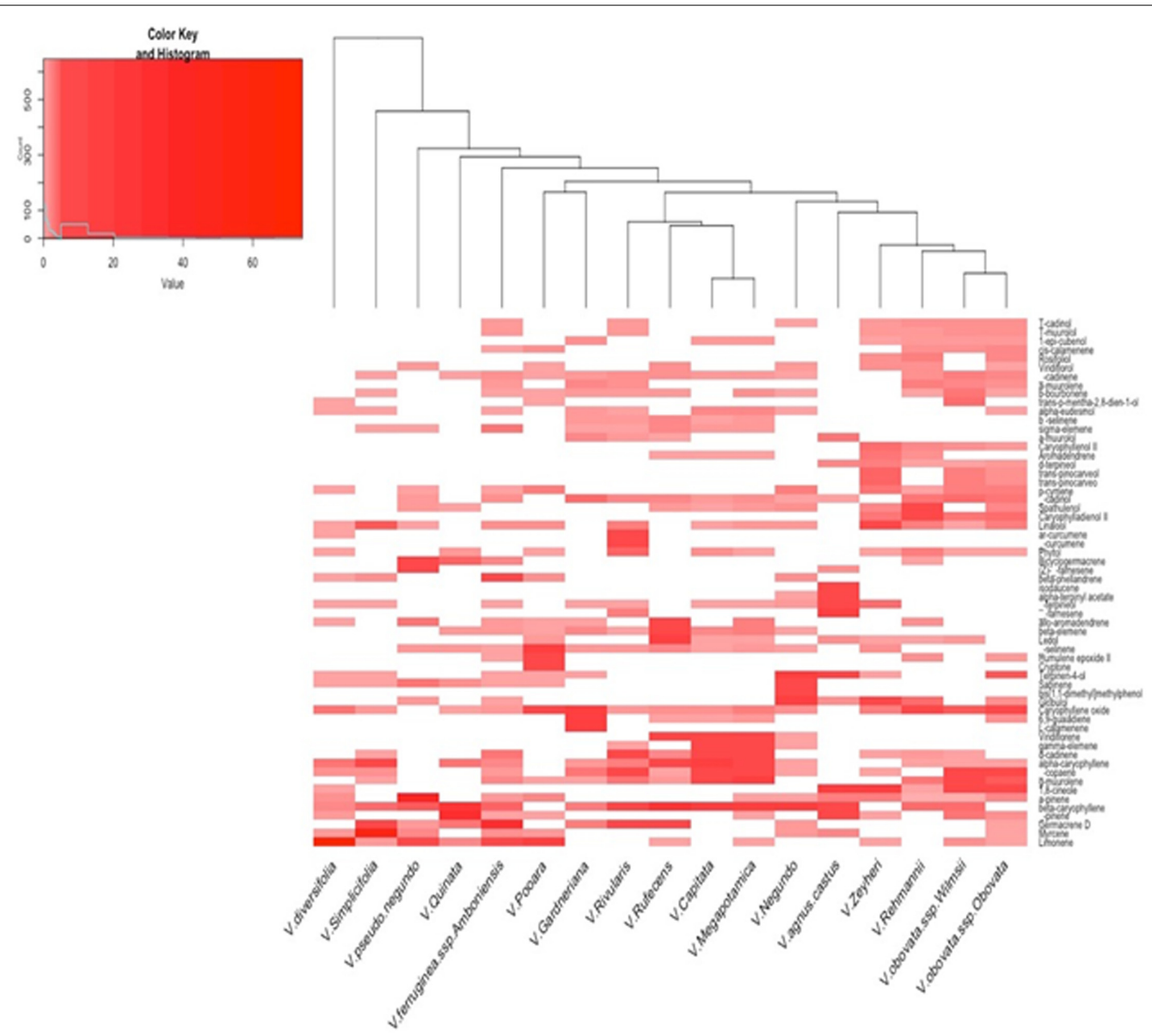

FIGURE 2 | Heat map of the volatile compounds characterized from essential oil extracts via GC-MS FID of 17 Vitex species. Heat map was generated using Euclidean Distance and the Unweighted Pair Group Method with Arithmetic Mean cluster algorithm. Compounds representing at least 2\% of the GC-FID signal were included (for a listing of compounds, see Supplementary Table S1). 


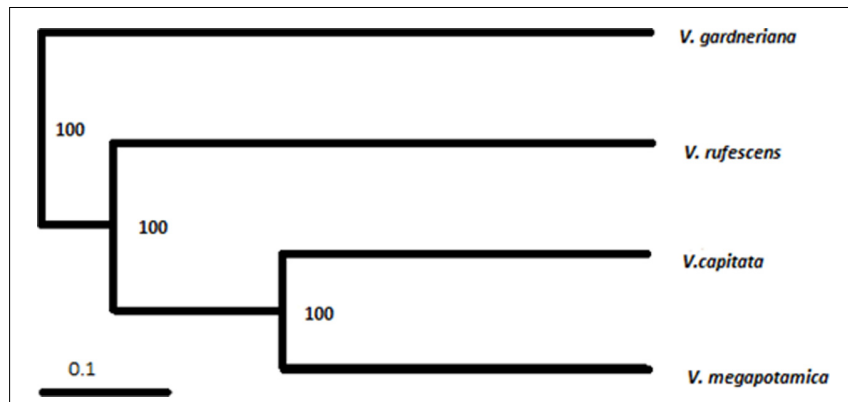

FIGURE 3 | Dendrogram of genetic similarity based on data from Inter-Simple Sequence Repeat profiling using the Jaccard coefficient and the Unweighted Pair Group with Arithmetic Mean method. Numbers indicate values generated with 100,000 bootstrap repetitions.

\section{DISCUSSION}

To our knowledge, this is the first report of the chemical composition and biological activity of the essential oil distilled from leaves of $V$. capitata, $V$. gardneriana and $V$. rufescens. Of the chemical constituents detected, 88.7, 94.5, 80.5, and $90.2 \%$ were sesquiterpenes, and $2.3,0.3,17.1$, and $8.6 \%$ were monoterpenes for $V$. capitata, $V$. megapotamica, $V$. gardneriana and $V$. rufescens, respectively. Similar chemical compositions were found in the essential oil extracts from $V$. capitata and $V$. megapotamica, where $\alpha$-copaene, (E)-caryophyllene, $\gamma$-elemene, $\alpha$-humulene, $\gamma$-muurolene, viridiflorene and $\gamma$-cadinene were the major components (Figure $\mathbf{2}$ and Table 2). Characterization of $V$. gardneriana revealed that the most abundant compounds were 6,9-guaiadiene (19.3\%), caryophyllene oxide (18.6\%), L-calamenene (13.9\%) and $\alpha$-cadinol (3.8\%). In the case of $V$. rufescens, $(E)$-caryophyllene (21\%), ledol (15.7\%) and germacrene D (9.3\%) were the main constituents detected.

Chemotaxonomy, or chemical variation in a group of compounds, is one of the tools used to define intra- and interspecific variability in plants (Sena Filho et al., 2007, 2012; DuranPeña et al., 2015). Our objective was to use the chemical profile in the four Vitex species we studied, plus 13 others from the literature, to develop a system for classification of plant specimens derived from this genus. The content of sesquiterpenes with seven and nine members in their ring system in the four Vitex species described in this study was remarkable. Recently, genes responsible for sesquiterpene cyclization were evaluated in fungi, which involved scaffolds generated by terpene synthases and cyclases (Quin et al., 2014). Our data indicates that sesquiterpene synthase is likely highly expressed in this genus and hypothesize that this enzyme plays an important role in its chemosystematics. Enzyme mechanisms of sesquiterpene biosynthesis are well known: 5-epi-aristolochene synthase (TEAS) found in Nicotiana tabacum L. (tobacco) was the first cloned and sequenced sesquiterpene synthase from Angiospermae species (Maillea et al., 2006), and could serve as a useful model for understanding how these compounds are built in the plant.
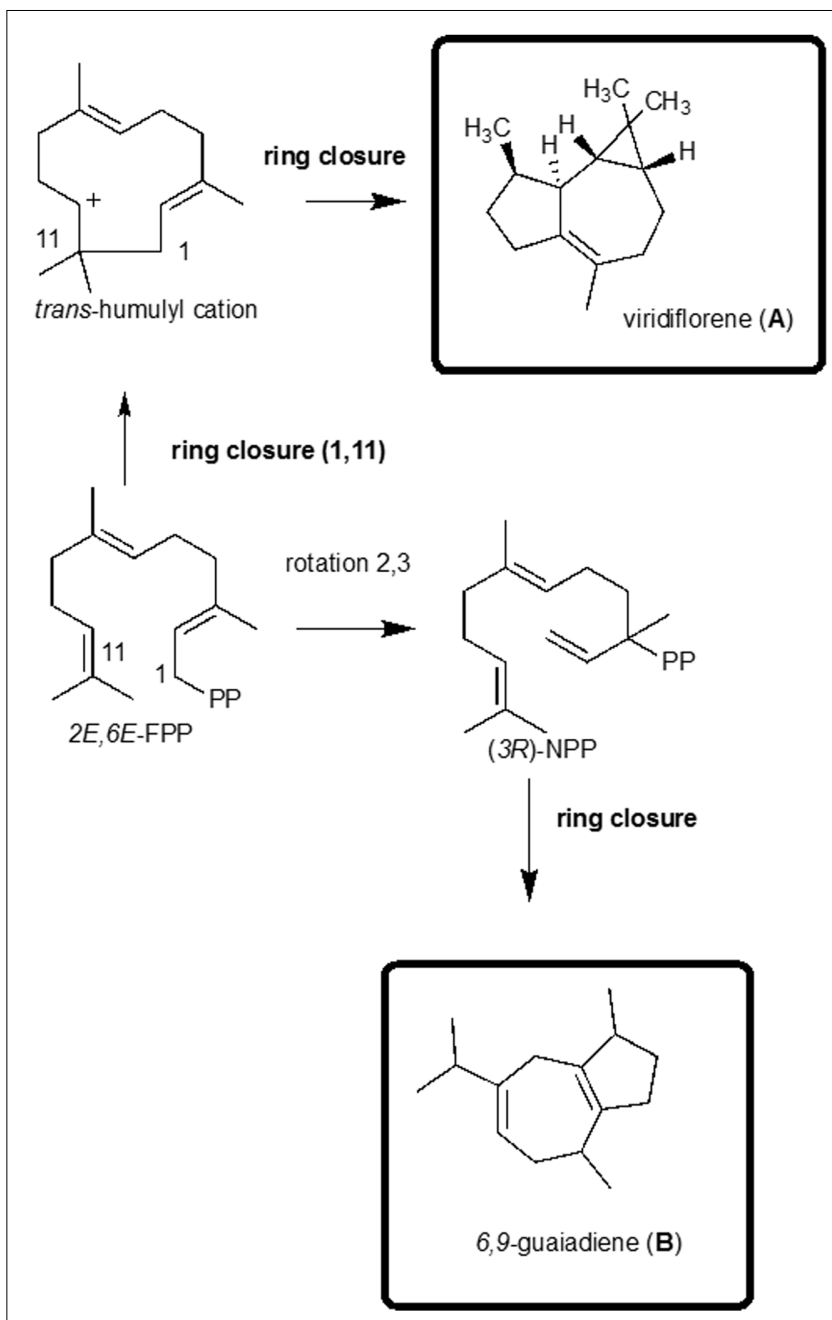

FIGURE 4 | Biosynthesis of the 5,10-cycloaromadendrane type sesquiterpenoids and the seven-member ring compounds found in Vitex species viridiflorene (A) and 6,9-guaidiene (B).

For both the chemical compound and genetic markers evaluated by clustering (Figures 1, 3), V. gardneriana was isolated from the other three species. This may be related to genotypic differences for this species, as it is found in a different biome (Sena Filho et al., 2008) which may influence the expression of genes used for synthesis of chemical compounds. The use of two data tools (chemical and genetic diversity) more thoroughly supports systematic characterization of the species studied (Rahalia et al., 2016), and validates our chemical marker proposal for the Vitex genus, namely, using the sesquiterpene skeleton with seven member rings as a biomarker candidate.

Interestingly, the chemical structure of the sesquiterpene viridiflorene found in $V$. megapotamica, $V$. capitata and $V$. rufescens possesses a very unique ring system, similar to 6,9-guaiadiene found in V. garnderiana (Figure 4). The enzymatic activity of recombinant Escherichia coli in TPS 31 from Solanum lycopenium led to the discovery of viridiflorine synthase 
(Bleeker et al., 2011). This compound possesses a similar structure to the africanone scaffold with a 2,6 ring closure (Quin et al., 2014); this type of ring closure could be considered as a more specific signature of the chemoprofile for species in the Vitex genus.

In the toxicity bioassays, the essential oil extracted from $V$. gardneriana was highly toxic to A. guerreronis, indicating its potential for use in controlling this major coconut pest. On the other hand, it was not possible to estimate the $\mathrm{LC}_{50}$ from $V$. capitata, $V$. megapotamica and $V$. rufescens essential oils. This differential toxicity may be explained by the diversity and amount of sesquiterpenes found only in V. gardneriana, such as 6,9-guaiadine (19\%), L-calamenene (13.9\%), and caryophyllene oxide (18.6\%). However, these compounds should be further evaluated concerning the toxicity to A. guerreronis using more modern toxicology bioassays. Further, predatory mites, especially those belonging to the family Phytoseiidae, are natural enemies of A. guerreronis worldwide (McMurtry and Croft, 1997; Návia et al., 2013). These beneficial mites are naturally found foraging on coconut plants and help to control A. guerreronis. Therefore, future research should also assess the acaricidal activity of $V$. gardneriana essential oil to predatory mites aiming at determining its selectivity toward non-target organisms, including pollinators and seed dispersers.

Biological activity of some of the prominent compounds we saw in the Vitex species studied here has been defined previously: 6,9-guaiadiene, prominent in $V$. gardneriana, was also found in essential oils extracted from Bracteosa ruilopezia (Standl.) Cuatrec and Baccharis salicifolia (Ruiz \& Pav.) Pers. (Asteraceae)both oils demonstrated antibacterial activity (Carrizo et al., 2009). It has also been suggested that caryophyllene oxide is toxic; this was evaluated using a direct spray test for females and eggs of the predatory mite Neoseiulus californicus (McGregor) (Momen et al., 2014). Further, $\alpha$-cadinol and caryophyllene oxide were the main volatile compounds found in essential oil extracted from aerial parts of Teucrium polium L. - Lamiaceae. The essential oil showed fumigant and repellency effects against the cowpea weevil Callosobruchus maculatus F. (Coleoptera: Bruchidae) (Khani and Asghari, 2012; Khani and Heydarian, 2014). $\alpha$-Cadinol also showed excellent inhibitory action against the termite Coptotermes formosanus Shiraki (Isoptera: Rhinotermitidae) (Cheng et al., 2014).

\section{REFERENCES}

Adams, R. P. (2007). Identification of Essential Oil Components by Gas Chromatography/Mass Spectrometry. Carol Stream, IL: Allured Publ. Corp.

Aliferis, K. A., Cubeta, M. A., and Jabaji, S. (2013). Chemotaxonomy of fungi in the Rhizoctonia solani species complex performing GC/MS metabolite profiling. Metabolomics 9, 159-169. doi: 10.1007/s11306-011-0340-1

Allwood, J. W., De Vos, R. C. H., Moing, A., Deborde, C., Erban, A., Kopka, J., et al. (2011). Plant metabolomics and its potential for systems biology research background concepts, technology, and methodology. Methods Enzymol. 500, 299-336. doi: 10.1016/B978-0-12-385118-5.00016-5

Barroso, G. M., Morim, M. P., Peixoto, A. L., and Ichaso, C. L. F. (1999). Frutos e Sementes: Morfologia Aplicada à Sistemática de Dicotiledôneas. Viçosa: UFV.

\section{CONCLUSION}

By combining the volatile profiles and ISSR molecular markers using bioinformatic tools, we were successful in clustering the Vitex species in order to identify markers for chemosystematic classification. In this work, $V$. gardneriana was isolated from the other species, expanding our understanding of the chemodiversity of this genus. In addition, the volatile components extracted from V. gardneriana showed potential for controlling A. guerreronis, as it was highly toxic to this coconut pest.

\section{AUTHOR CONTRIBUTIONS}

Conceived and designed experiments: JdSF, IB, AT, and HX. Conducted experiments: JdSF and IB. Analyzed data: JdSF, IB, AT, PN, DS, provided reagents: ACdS, AT, and JdSF. Wrote the manuscript: JdSF, AR, ASF, AT, DS, and JD.

\section{FUNDING}

We would like to thank the Coordenação de Aperfeiçoamento de Pessoal de Nível Superior (CAPES) and the Conselho Nacional de Desenvolvimento Científico e Tecnológico (CNPq) (405485/2016-6) for funding.

\section{ACKNOWLEDGMENTS}

We would like to thank the Empresa Brasileira de Pesquisa Agropecuária (EMBRAPA), CAPES, and CNPq 405485/2016-6 for contributing to this work.

\section{SUPPLEMENTARY MATERIAL}

The Supplementary Material for this article can be found online at: https://www.frontiersin.org/articles/10.3389/fpls.2017.01931/ full\#supplementary-material

TABLE S1 | Major components (\%) determined in essential oil extracts from 17 Vitex species.

Bittrich, V., Nascimento-Junior, J. E., Amaral, M. C. E., and Lima Nogueira, P. C. (2013). The anther oil of Symphonia globulifera L.f. (Clusiaceae). Biochem. Syst. Ecol. 49, 131-134. doi: 10.1016/j.bse.2013.03.011

Bleeker, P. M., Spyropoulou, E. A., Diergaarde, P. J., Volpin, H., De Both, M. T. J., Zerbe, P., et al. (2011). RNA-seq discovery, functional characterization, and comparison of sesquiterpene synthases from Solanum lycopersicum and Solanum habrochaites trichomes. Plant Mol. Biol. 77, 323-336. doi: 10.1007/ s11103-011-9813-x

Bohlmann, J., Meyer-Gauen, G., and Croteau, R. (1998). Plant terpenoid synthases: molecular biology and phylogenetic analysis. Proc. Natl. Acad. Sci. U.S.A. 95, 4126-4133. doi: 10.1073/pnas.95.8.4126

Carrizo, F. R., Ponzi, M., and Ardanaz, C. (2009). Chemical composition of essential oil of Baccharis salicifolia (Ruiz \& Pavon) Pers. and 
antibacterial activity. J. Chil. Chem. Soc. 54, 475-476. doi: 10.4067/S071797072009000400034

Cheng, S. S., Lin, C. Y., and Chen, Y. J. (2014). Insecticidal activities of Cunninghamia konishii Hayata against Formosan subterranean termite Coptotermes formosanus (Isoptera: Rhinotermitidae). Pest Manag. Sci. 70, 1215-1219. doi: 10.1002/ps.3673

Dettmer, K., Aronov, P. A., and Hammock, B. D. (2007). Mass spectrometry-based metabolomics. Mass Spectrom. Rev. 26, 51-78. doi: 10.1002/mas.20108

Doyle, J. (1991). "DNA protocols for plants - CTAB total DNA isolation," in Molecular Techniques in Taxonomy, eds G. M. Hewitt and A. Johnston (Berlin: Springer), 283-293.

Duran-Peña, M. J., Ares, J. M. B., Hanson, J. R., Collado, I. G., and HernandezGalan, R. (2015). Biological activity of natural sesquiterpenoids containg a gem dimethylcyclopropane unit. Nat. Prod. Rep. 32, 1236-1248. doi: 10.1039/ c5np00024f

Feitosa-Alcantara, R. B., Bacci, L., Blank, A. F., Alves, P. B., Silva, I. M. A., Soares, C. A., et al. (2017). Essential oils of Hyptis pectinata chemotypes: isolation, binary mixtures and acute toxicity on leaf-cutting ants. Molecules 22:621. doi: 10.3390/molecules22040621

Ghislain, M., Zhang, D., Fajardo, D., Huamann, Z., and Hijimans, R. H. (1999). Marker assisted sampling of the cultivated Andean potato Solanum phureja collections using RAPD markers. Genetic Res. Crop Evol. 6, 547-555. doi: 10.1023/A:1008724007888

Hammer, Ø, Harper, D. A. T., and Ryan, P. D. (2001). PAST: paleontological statistics software package for education and data analysis. Palaeontol. Electron. 4:9.

Jaccard, P. (1908). Nouvelles recherches sur la distribution florale. Soc. Vaud. Sci. Nat. 44, 223-270.

Jing, L., Lei, Z., Zhang, G., Pilon, A. C., Huhman, D. V., Xie, R., et al. (2015). Metabolite profiles of essential oils in citrus peels and their taxonomic implications. Metabolomics 11, 952-963. doi: 10.1007/s11306-014-0751-x

Khani, A., and Asghari, J. (2012). Insecticide activity of essential oils of Mentha longifolia, Pulicaria gnaphalodes and Achillea wilhelmsii against two stored product pests, the flour beetle, Tribolium castaneum, and the cowpea weevil, Callosobruchus maculatus. J. Insect. Sci. 12:73. doi: 10.1673/031.012.7301

Khani, A., and Heydarian, M. (2014). Fumigant and repellent properties of sesquiterpene-rich essential oil from Teucrium polium subsp capitatum (L.). Asian Pac. J. Trop. Med. 7, 956-961. doi: 10.1016/S1995-7645(14)60169-3

Lima, C. T., and Rança, F. F. (2009). Flora da Bahia: Vitex tour.ex. L. Lamiaceae. Sitientibus 9, 225-244.

Linstrom, P. J., and Mallard, W. G. (2005). NIST Chemistry Webbook, NIST Standard Reference Database Number 69. Gaithersburg: National Institute of Standards and Technology.

Maillea, P. E., Chappel, J., and Noel, J. P. (2006). Biosynthetic potential of sesquiterpene synthases: alternative products of tobacco 5-epi-aristolochene synthase. Arch. Biochem. Biophys. 448, 73-78. doi: 10.1016/j.abb.2005.10.028

McMurtry, J. A., and Croft, B. A. (1997). Life-styles of phytoseiid mites and their roles in biological control. Annu. Rev. Entomol. 42, 291-321. doi: 10.1146/ annurev.ento.42.1.291

Momen, F. M., Rahman, H. A. A., and Samour, E. A. (2014). Acaricidal activity of Melissa officinalis oil and its formulation on Tetranychus urticae and the predatory mite Neoseiulus californicus (Acari: Tetranychidae and Phytoseiidae). Acta Phytopathol. Entomol. Hung. 49, 95-115. doi: 10.1556/APhyt.49.2014.1.10

Návia, D., Gondim, M. G. C., Aratchige, N. S., and Moraes, G. J. (2013). A review of the status of the coconut mite, Aceria guerreronis (Acari: Eriophyidae), a major tropical mite pest. Exp. Appl. Acarol. 59, 67-94. doi: 10.1007/s10493-0129634-x

Oliveira, N. N. F. C., Galvão, A. S., Amaral, E. A., Santos, A. W. O., Sena Filho, J. G., Oliveira, E. E., et al. (2017). Toxicity of vegetable oils to the coconut mite Aceria guerreronis and selectivity against the predator Neoseiulus baraki. Exp. Appl. Acarol. 72, 23-34. doi: 10.1007/s10493-017-0134-x

Page, R. D. M. (1996). TreeView: an application to display phylogenetic trees on personal computers. Comput. Appl. Biosci. 12, 357-358. doi: 10.1093/ bioinformatics/12.4.357
Pavlicek, A., Hrda, S., and Flegr, J. (1999). FreeTree - freeware program for construction of phylogenetic trees on the basis of distance data and bootstrap/jackknife analysis of the tree 32 robustness Frenkelia. Folia Biol. 45, 97-99.

Quin, M. B., Flynn, C. M., and Schmidt-Dannert, C. (2014). Traversing the fungal terpenome. Nat. Prod. Rep. 31, 1449-1473. doi: 10.1039/c4np00075g

Rahalia, F. Z., Lamineb, M., Gargourib, M., Rebeya, I. B., Hammamia, M., and Sellamia, I. H. (2016). Metabolite profiles of essential oils and molecular markers analysis to explore the biodiversity of Ferula communis: towards conservation of the endemic giant fennel. Phytochemistry 124, 58-67. doi: 10.1016/j.phytochem.2016.01.012

Ramos, J. M. O., Santos, C. A., Santana, D. G., Santos, D. A., Alves, P. B., and Thomazzi, S. M. (2013). Chemical constituents and potential anti-inflammatory activity of the essential oil from the leaves of Croton argyrophyllus. Rev. Bras. Farmacogn. 23, 644-650. doi: 10.1590/S0102-695X2013005000045

Robertson, J. L., Russell, R. M., Preisler, H. K., and Savin, N. E. (2007). Pesticide Bioassays with Arthropods. Boca Raton: CRC press.

Salimena-Pires, F. R., and Giulietti, A. M. (1998). Flora da serra do cipó, minas gerais: verbenaceae. Bol. Botânica 17, 155-186. doi: 10.11606/issn.2316-9052. v17i0p155-186

Sena Filho, J. G., Duringer, J. M., Maia, G. L. A., Tavares, J. F., Xavier, H. S., Cunha, E. V. L., et al. (2008). Ecdysteroids from Vitex species: distribution and compilation of their 13C-NMR spectral data. Chem. Biodivers. 5, 707-713. doi: 10.1002/cbdv.200890067

Sena Filho, J. G., Duringer, J. M., Uchoa, D. E. A., Xavier, H. S., Barbosa Filho, J. M., and Braz Filho, R. (2007). Distribution of iridoid glycosides in plants from the genus Lippia (Verbenaceae): an investigation of Lippia alba (Mill.) N.E. Brown. Nat. Prod. Commun. 2, 715-716.

Sena Filho, J. G., Rabbani, A. R. C., Silva, T. R. S., Silva, A. V. C., Souza, I. A., Santos, M. J. B. A., et al. (2012). Chemical and molecular characterization of fifteen species from the Lantana (Verbenaceae) genus. Biochem. Syst. Ecol. 45, 130-137. doi: 10.1016/j.bse.2012.07.024

Sena Filho, J. G., Xavier, H. S., Barbosa Filho, J. M., and Duringer, J. M. (2010). A chemical marker proposal for the Lantana genus: Composition of the essential oils from the leaves of Lantana radula and L. canescens. Nat. Prod. Commun. 5, 635-640.

Silva, A. C. B., Teodoro, A. V., Oliveria, E. E., Rêgo, A. S., and Silva, R. R. (2013). Toxicity of neem oil to the cassava green mite Mononychellus tanajoa (Bondar) (Acari: Tetranychidae). Chil. J. Agric. Res. 73, 315-319. doi: 10.4067/S071858392013000300016

Sokal, R. R., and Michener, C. D. (1958). A statistical method for evaluating systematic relationships. Univ. Kans. Sci. Bull. 38, 1409-1438.

van Den Dool, H., and Kratz, P. D. (1963). A generalization of the retention index system including linear temperature programmed gas-liquid partition chromatography. J. Chromatogr. 11, 463-471. doi: 10.1016/S0021-9673(01) 80947-X

Weng, J., and Noel, J. P. (2013). Chemodiversity in Selaginella: a reference system for parallel and convergent metabolic evolution in terrestrial plants. Front. Plant Sci. 4:119. doi: 10.3389/fpls.2013.00119

Zhao, K. G., Zhou, M. Q., Chen, L. Q., Zhang, D., and Robert, G. W. (2007). Genetic diversity and discrimination of Chimonanthus praecox (L.) link germplasm using ISSR and RAPD markers. Hortscience 42, 1144-1148.

Conflict of Interest Statement: The authors declare that the research was conducted in the absence of any commercial or financial relationships that could be construed as a potential conflict of interest.

Copyright (C) 2017 de Sena Filho, Barreto, Soares Filho, Nogueira, Teodoro, Cruz da Silva, Xavier, Rabbani, Spakowicz and Duringer. This is an open-access article distributed under the terms of the Creative Commons Attribution License (CC BY). The use, distribution or reproduction in other forums is permitted, provided the original author(s) or licensor are credited and that the original publication in this journal is cited, in accordance with accepted academic practice. No use, distribution or reproduction is permitted which does not comply with these terms. 